\title{
Digital Storytelling vs. Oral Storytelling: An Analysis of the Art of Telling Stories Now and Then
}

\author{
Yee Bee Choo ${ }^{1, *}$, Tina Abdullah ${ }^{2}$, Abdullah Mohd Nawi ${ }^{2}$ \\ ${ }^{1}$ Department of Language, Institute of Teacher Education Tun Hussein Onn Campus, Malaysia \\ ${ }^{2}$ Faculty of Social Sciences and Humanities, Universiti Teknologi Malaysia, Malaysia
}

Received January 22, 2020; Revised April 1, 2020; Accepted April 21, 2020

Copyright $\bigcirc 2020$ by authors, all rights reserved. Authors agree that this article remains permanently open access under the terms of the Creative Commons Attribution License 4.0 International License

\begin{abstract}
Generally, oral storytelling is an ancient art of telling stories that has been passed down from generation to generation while digital storytelling incorporates technology which consists of various multimedia modes such as graphics, audio, texts, videos and animations. This paper analyses the differences between the two strategies by discussing their differences in four aspects: (1) the use of technology, (2) the role of storyteller, (3) the approach of process and product, and (4) the engagement of audience. The analysis aims to create awareness among academicians about these differences and highlight that digital storytelling is the combination of both the art of storytelling and digital story. Then, this paper provides a critical review of empirical studies on the potentials of using digital storytelling in teaching and learning for education. The results have shown that the use of digital storytelling is not only beneficial in developing the teachers' content, pedagogical and technological knowledge, but also in enhancing their students' learning as it increases their understanding of content and caters for their multiple intelligence. This study suggests the implementation of digital storytelling in teaching and learning in the classroom and future directions for research are suggested.
\end{abstract}

Keywords Digital Storytelling, Oral Storytelling, Technology, Teaching and Learning

\section{Introduction}

The emergence of technology brings new dimensions to language learning as it offers learners new avenues to explore target language in its functional use (Lee, 2014). Integration of salient new technologies is also one of the underlying pedagogical principles in the primary school syllabus in Malaysian education (Ministry of Education, 2013). Recently, academicians have advocated the use of technology in teaching and learning strategies through digital storytelling. Digital storytelling incorporates technology which consists of various multimedia modes such as graphics, audio, texts, videos and animations meanwhile traditional oral storytelling is an ancient art of telling stories that has been passed down from generation to generation and it precedes modern technology and historical record-keeping (Maddin, 2012). This paper presents an analysis that aims to create awareness among the teachers about the differences between the two types of storytelling and provide a review on the potentials of using digital storytelling in teaching and learning.

\section{Objectives}

The objectives are to:

1. identify the differences between oral storytelling and digital storytelling

2. identify the potentials of using digital storytelling in teaching and learning

\section{Literature Review}

Storytelling is an oral tale that was passed on by word of mouth from generation to generation. Dujmović (2006) explains that storytelling is the art of narrating a tale from memory rather than by reading. It is a very different activity to story reading due to the breadth of opportunities present in storytelling that it engages the audience or listeners and makes them participators rather than passive hearers (Daniel, 2007). Likewise, Hsu (2010) defines storytelling as "the use of voice, facial expressions, gestures, eye contact, and interaction to connect a tale with listeners" (p.7). Therefore, storytelling is a two-way 
interaction between the storyteller and the listeners or audience where the storyteller needs to use the crafts of storytelling in order to get the feedback from the audience.

Storytelling remains in a constant process of variation, depending on the memory, talent, or purpose of the storytellers (Anderson, 2002). The storyteller might modify the story based on his choice of setting and detail, and the rapport between him and the audience (Dujmović, 2006). The building materials used by the storytellers are words, sounds, and language patterns while the tools are the voice projection, facial expression, and hand gestures, and the product is the shared human experience creation. Thus, storytelling is largely about bringing characters to life, so the storytellers and the audience can experience the emotions and thoughts of these characters. Using features such as diction, voice projection, intonation, gesture, facial expressions and so on are an excellent way to bring characters to life. Therefore, teachers are encouraged to use storytelling as a teaching and learning strategy in the classroom to engage their students.

\subsection{Differences between Oral Storytelling and Digital Storytelling}

Oral storytelling is a powerful tool for teaching and learning as it engages the students' mental imagery and imagination of the story. According to Dujmović (2006), oral storytelling enables the students to connect the story to their own lives so that they understand human behaviour. By listening to the story, the students not only learn the language skills in vocabulary and reading comprehension, but they also learn to understand the universal truth of human relationship and dealing with others. However, with the technological affordances of today's world, digital storytelling is suggested as one possibility that places technology as a meaningful tool for teaching and learning (Harriman, 2011). This section will discuss the differences between oral storytelling and digital storytelling in teaching and learning in four aspects: (1) the use of technology, (2) the role of storyteller, (3) the approach of process and product, and (4) the engagement of audience.

Firstly, digital storytelling differs from conventional oral storytelling in an important way: the use of technology. Both the oral and digital storytellers deliver their story orally to the audience but they use different means to deliver it. McLellan (2006) defines digital storytelling as "the art and craft of exploring different media and software applications to communicate stories in new and powerful ways using digital media" (p. 66) while Robin (2011) simply defines digital storytelling as the practice of using computer-based tools to tell stories. Therefore, digital storytelling is different from oral storytelling in that it uses technological tools to enhance the storytelling.

Secondly, the roles played by the two storytellers are different. A traditional storyteller only tells story orally to communicate and share information. It is delivered orally so that the information can be shared immediately to the audience without writing down the notes. Whereas, a digital storyteller has an additional role of an author and it has proved to be a practical and simple way to promote authorship (Harriman, 2011). He needs to do research on a related topic before drafting and writing the story. Then, he spends some time in writing the story and uses the technological tools to insert images and music to make the story interesting. Though it takes a longer time for a digital storyteller to prepare for his presentation compared to a traditional storyteller, he becomes more creative during the designing process when he selects a topic, conducts the research, writes a script, and develops the story.

Besides, oral storytelling is process-based while digital storytelling is process and product-based. The oral storytellers modify the content of the story every time it is told, emphasising various aspects depending on the audience or, indeed, the mood of the storyteller. He may add or delete the details during storytelling. Such an organic approach is also available to the digital storyteller and his audience. But digital storytelling can be available as a product. Once the story is committed to a digital format and shared in the digital area, it becomes static as a product. Though the content is fixed, the digital storyteller can modify it by pausing the digital story. The story can be stored and retrieved and the digital storyteller can access the content anytime.

Another difference between oral storytelling and digital storytelling is the engagement of the audience. In oral storytelling, the audience hears the story and needs to imagine the story mentally to understand the story. This might pose a huge cognitive challenge to them (Sundmark, cited in Wallin, 2015) hence making them passive listeners. However, in digital storytelling, the audience can watch the visuals and hear the music or soundtrack to help them understand the story in a vivid way. Rule (2010) suggests that digital storytelling is powerful as it integrates images, music, narrative and voice which bring life to characters, situations, experiences, and new understanding. Like the oral storyteller, the digital storyteller uses crafts of storytelling such as voice projection, facial expressions and so on to tell the story when he is speaking directly to the audience. He also uses digital media such as images and sounds to help his audience understand his story. Atta-Alla (2012) claims that when storytelling is more engaging and becoming contextualised, consequently it raises the audience's interest in listening to stories. As the audience could listen to the digital storyteller and watch the visuals, they understand the story easily, so they are more active and engaged during the face-to-face interaction. Therefore, the digital storyteller can get the audience to be more actively involved compared to the oral storyteller.

The engagement of the audience can be influenced by the number of audience for both oral and digital storytelling. Oral storytelling is commonly conducted in a 
small group of audience while digital storytelling can involve a wider audience as separate individuals could watch the online digital story during their free time. As digital information, the digital story can be stored, archived, transferred, or uploaded to the web (Davis, 2004). Thus, digital storytelling can be watched by individuals and a group of people in a setting such as a classroom where they can exchange their ideas and opinions about digital storytelling.

The feedback received through oral storytelling is immediate while digital storytelling can be immediate and delayed. In oral storytelling, the storyteller can get the feedback orally from the audience immediately through their facial expressions and verbal responses. Then, he will vary his intonation or change his crafts of storytelling according to what he observes from his audience. On the other hand, the digital storyteller can receive both oral and written online feedback from the audience. Though online feedback is delayed, it provides time for him to interact with the audience. Meadow (2003) believes that digital storytelling is the social practice of telling stories as the engagement between the storyteller and audience involves social interaction. This is because when the audience gives immediate and delayed feedback by asking questions and seeking for clarification, they are more engaged with the storyteller, thus there is more interaction between the audience and storyteller. Table 1 summarises the differences between oral storytelling and digital storytelling that have been discussed earlier.

Table 1. Comparison of digital storytelling and oral storytelling

\begin{tabular}{cll}
\hline No. & \multicolumn{1}{c}{ Oral Storytelling } & \multicolumn{1}{c}{ Digital Storytelling } \\
\hline 1. & No use of technology & Focus on technology \\
\hline 2. & Less time in preparation & $\begin{array}{l}\text { More time in preparation (by } \\
\text { doing research, looking for the } \\
\text { images and music) }\end{array}$ \\
\hline 3. & No writing process & Drafting and rewriting \\
\hline 4. & Process-based & Process and product-based \\
\hline 5. & Content can be modified & $\begin{array}{l}\text { Content is fixed but can be } \\
\text { modified }\end{array}$ \\
\hline 6. & $\begin{array}{l}\text { Story can be accessed } \\
\text { through oral narratives }\end{array}$ & $\begin{array}{l}\text { Story can be retrieved and } \\
\text { accessed through oral } \\
\text { narratives told by storyteller }\end{array}$ \\
\hline 7. & $\begin{array}{l}\text { Audience need to imagine } \\
\text { the story mentally }\end{array}$ & $\begin{array}{l}\text { Audience can watch the } \\
\text { visuals on digital form }\end{array}$ \\
\hline 8. & Audience is passive & $\begin{array}{l}\text { Audience is active and } \\
\text { engaged }\end{array}$ \\
\hline 9. & Involve a group of people & $\begin{array}{l}\text { Involve a group of people and } \\
\text { individuals }\end{array}$ \\
\hline 10. & Oral feedback & $\begin{array}{l}\text { Oral and written / online } \\
\text { feedback }\end{array}$ \\
\hline 11. & Immediate feedback & $\begin{array}{l}\text { Immediate and delayed } \\
\text { feedback }\end{array}$ \\
\hline
\end{tabular}

In sum, digital storytelling for this study is an art of storytelling combined with digital story. The digital storyteller designs a story by using multimedia modes, including images, audio, text, and video. Then, he uses technology effectively with the crafts of storytelling that involves the audience. The analyses of the differences between oral storytelling and digital storytelling have shown that digital storytelling is better than oral storytelling in some ways and the next section will provide a critical review of empirical studies on its potentials in teaching and learning.

\subsection{Potentials of Digital Storytelling in Teaching and Learning}

There are a number of ESL studies that have demonstrated the potentials of using digital storytelling in teaching and learning. This section will discuss its potentials in developing the teachers' content, pedagogical and technological knowledge, as well as its advantages to enhance their students' learning.

Firstly, using digital storytelling could develop the teachers' content knowledge. In creating a digital story, the teachers engage in higher erder thinking (e.g., critical, creative, and reflective thinking) as they create content through understanding, synthesis, and evaluation by making use of the information (Sadik, 2008). In a research carried out by Hur and Suh (2012), they found that the teachers were active learners when they explored the contents used for their digital stories. Through the design of the digital story, they select stories with its criteria in the plot, characters, theme and moral values which develops their critical understanding of cultural, social and historical contexts in content knowledge.

Secondly, digital storytelling develops the teachers' pedagogical knowledge as they could use it as an instructional tool. They could show the digital stories to their students to introduce content which could serve as an anticipatory set or hook to capture students' attention when presenting new ideas (Robin, 2008). It also helps to make an abstract or conceptual content more understandable (Robin, 2008). Teachers who use digital storytelling may find that it is very helpful to engage their students in the discussion of the story.

Besides, the teachers could use digital storytelling to engage students through fun and meaningful activities. One of the learning standards outlined for Language Arts in the Malaysian English syllabus is to stimulate students' imagination and interest so that they will use English language extensively (Ministry of Education, 2011). The teaching of Language Arts should ensure that the students benefit from hearing and using language from fictional and non-fictional sources (Ministry of Education, 2011). Through digital storytelling, the students are able to hear the language (aural) and speak the language (oral), thus they are more exposed to the usage of English language. Therefore, teachers could use digital storytelling in their pedagogy to engage their students.

Furthermore, the teachers could develop their knowledge of technology through digital storytelling. According to Ohler (2008), the process of crafting digital 
story affords teachers opportunities to build $21^{\text {st }}$-century skills in 4C including critical and creative thinking, collaboration and communication. The teachers becomes critical in selecting multimodal means, including multimodal (e.g., audio, video, animation) and multimedia forms of communication (e.g., text, image, voice) to compile the digital story. A study of a four-week digital story project revealed that when the ESL students create their own personal digital stories, they enhanced their written, visual, and digital literacies (Alameen, 2011). By designing digital stories, they become authors as they produce their own educational product content and this would motivate them in creating more digital stories in the story-making and sharing process. Therefore, the process of digital story production enhances the teachers' creativity when they deal with digital images, text and sound to construct narratives.

Moreover, the creation process of digital storytelling could facilitate the teachers' communication and collaboration when they actively participate in it (Jakes \& Brennan, 2005). Harriman (2011) agrees that it engages the teachers in a participatory rather than a passive process. They develop enhanced communication skills as they learn to conduct research on a topic, ask questions, organise their ideas, express opinions, and construct meaningful narratives. Reinders (2011) agrees that digital story develops their information literacy along with their communicative abilities as well as their interpersonal skills in teamwork and collaboration when they do in pairs or small groups. Those who experience the designing process of digital story may learn to critique their own work, and the work of others which could facilitate social learning. Tiba, Condy, Chigona, and Tunjera (2013) had found that digital storytelling could promote acquisition of multiple skills such as reading, writing, critical thinking, problem-solving, technological skills and communication skills. Thus, the process of creating the digital story enables the teachers to develop their technological knowledge.

While potentials of digital storytelling in classrooms have been recognised, digital storytelling can only be effective and widely used if teachers integrate the content knowledge (subject matter) and pedagogical knowledge (teaching methods) with technology (digital storytelling). They also need to optimise these knowledge areas in their teaching beliefs and put them into practice in their classroom to enhance their students' learning.

Digital storytelling could help the teachers to increase their students' understanding of the content. Researchers such as Burmark (2004) had found that integrating visual images with written text enhanced and accelerated student comprehension while Ohler (2008) found that digital storytelling had promoted student-centred learning. Tsou, Wang and Tzeng (2006) also reported students' improved story comprehension as well as increased sentence complexity in their story recalls. Yee, Abdullah and Mohd Nawi (2017)'s research had found that the students were able to understand the meaning of words and the story through the visual images. Therefore, using digital storytelling is beneficial for both the teachers and their students in their content knowledge.

Digital storytelling is also effective for student learning as it caters for multiple intelligences (Gardner, 1983). Students who prefer visuals could see the images, musical learners could hear the music, and linguistic learners could learn the words or vocabulary. It also appeals to students' interpersonal when they give opinions through interaction and their intrapersonal in understanding themselves after learning the story. Lynch and Fleming (2007) also indicate that the "flexible and dynamic nature of digital storytelling, which encapsulates aural, visual and sensory elements, utilises the multitude of cognitive processes that underpin learning - from verbal linguistic to spatial, musical, interpersonal, intrapersonal, naturalist and bodily-kinesthetic" (p. 7). Smeda, Dakich, and Sharda (2014) also support that digital storytelling can provide practical environment for students to engage their three different senses: hands, eyes and ears. This provides an opportunity for teachers to engage their students to learn in different potentials and interests.

\section{Conclusions}

This paper analyses the differences between oral and digital storytelling and the potentials of using digital storytelling in teaching and learning. The analysis has shown that the use of digital storytelling is more beneficial to the teachers and their students, thus suggesting its implementation in teaching and learning in the classroom. Future research is to conduct an empirical study on oral storytelling and digital storytelling to find out more about their differences and effectiveness, as well as to investigate the teachers' perceptions of using both strategies in teaching and learning.

\section{REFERENCES}

[1] Alameen, G. (2011). Learner digital stories in a Web 2.0 age. TESOL Journal, 2, 355-369.

[2] Anderson, N. (2002). Elementary children's literature. Boston: Allyn \& Bacon.

[3] Atta-Alla, M. (2012). Integrating language skills through storytelling. English Language Teaching (5), 12, 1-13.

[4] Burmark, L. (2004). Visual presentations that prompt, flash \& transform. Media and Methods. 40(6), 4-5.

[5] Daniel, A.K. (2007). From folktales to algorithms: Developing the teacher's role as principal storyteller in the classroom. Early Child Development and Care, 177:6-7, 


\section{5-750. doi: 10.1080/03004430701377664}

[6] Davis, A. (2004). Co-authoring identity: Digital storytelling in an urban middle school. THEN: Journal, 1(1). Retrieved from http://thenjournal.org:16080/feature/61/

[7] Dujmović, M. (2006). Storytelling as a method of EFL teaching. Metodički obzori : časopis za odgojno-obrazovnu teoriju i praksu, 1(1), 75-87. Retrieved from http://hrcak.srce.hr/11514

[8] Gardner, H. (1983). Frames of mind: The theory of multiple intelligences. New York: Basic Books.

[9] Harriman, C.L.S. (2011). The impact of TPACK and digital storytelling as a learning experience for pre-service teachers in a learning-by-designing project. Retrieved from https://getd.libs.uga.edu/pdfs/harriman_catia_s_201108_ph d.pdf

[10] Hsu, Y. (2010). The influence of English storytelling on the oral language complexity of EFL primary students. (Unpublished master thesis). National Yunlin University of Science \& Technology, Yunlin.

[11] Hur, J.W., \& Suh, S. (2012). Making learning active with interactive whiteboards, podcasts and digital storytelling in ELL classroom. Computers in the Scools: Interdisciplinary Journal of Practice, Theory and Applied Research, 29(4), 320-338. doi: 10.1080/07380569. 2012.734275.

[12] Jakes, D.S., \& Brennan, J. (2005). Capturing stories, capturing lives: An introduction to digital storytelling. Retrieved from http://www.jakesonline.org/dstory ice.pdf.

[13] Lee, L. (2014). Digital new stories: Building language learners' content knowledge and speaking skills. Foreign Language Annals, 47( 2), 338-356. doi: 10.1111/flan.12084

[14] Lynch, G., \& Fleming, D. (2007) Innovation through design: A constructivist approach to learning. LAB 3000, RMIT University. Retrieved from http://lab.3000.com.au/research /research/index.jsp.

[15] Maddin, E. (2012). Introducing TPCK to pre-service teachers through digital storytelling. In P. Resta (Ed.), Proceedings of SITE 2012--Society for Information Technology \& Teacher Education International Conference (pp. 1400-1406). Retrieved from https://www.learntechlib.org/p/39777.

[16] McLellan, H. (2006). Digital storytelling in higher education. Journal of Computing in Higher Education, 19(1), 65-79.

[17] Meadow, D. (2003). Digital storytelling: Research-based practice in new media. Visual Communication, 19(1), 65-79.

[18] Ministry of Education, Malaysia (2011). Dokumen standard kurikulum standard sekolah rendah: Bahasa Inggeris SK Tahun $1 \& 2$. Putrajaya: Curriculum Development Centre.

[19] Ministry of Education, Malaysia (2013). Kurikulum standard sekolah rendah: Dokumen standard kurikulum dan pentaksiran Bahasa Inggeris SK Tahun 4. Putrajaya: Curriculum Development Centre.

[20] Ohler, J. (2008). Digital storytelling in the classroom: New media pathways to literacy, learning, and creativity. Thousand Oaks, CA: Corwin Press.
[21] Reinders, H. (2011). Digital storytelling in the foreign language classroom. ELT World Online Journal, 3, 1-9.

[22] Robin, B.R. (2008). Digital storytelling: A powerful technology tool for the $21^{\text {st }}$ century classroom. Theory into $\begin{array}{lll}\text { Practice, } & 47(3), & 220-228,\end{array}$ $10.1080 / 00405840802153916$

[23] Robin, B. (2011). The educational uses of digital storytelling website. Retrieved from http://digitalstorytelling.coe.uh.edu

[24] Rule, L. (2010). Digital storytelling: Never has storytelling been so easy or so powerful. Knowledge Quest, 38(4), 56-57.

[25] Sadik, A. (2008). Digital storytelling: A meaningful technology-integrated approach for engaged student learning. Educational Technology Research and Development, 56(4), 487-506.

[26] Smeda, N., Dakich, E. \& Sharda, N. The effectiveness of digital storytelling in the classrooms: A comprehensive study. Smart Learn. Environ. 1, 6 (2014). https://doi.org/10.1186/s40561-014-0006-3

[27] Tiba, C., Condy, J., Chigona, A., \& Tunjera, N. (2013). Digital storytelling as a tool for teaching: Perceptions of pre-service teachers. TD The Journal for Transdisciplinary Research in Southern Africa, 10(3), 285-301.

[28] Tsou, W., Wang, W., \& Tzeng, Y. (2006). Applying a multimedia storytelling website in foreign language learning. Computers \& Education, 47, 17-28.

[29] Wallin, J. (2015). Storytelling and language development. Retrieved from https://muep.mau.se/bitstream/handle/2043 /18896/EX\%20FINAL.pdf?sequence=2.

[30] Yee, B.C., Abdullah, T., \& Mohd Nawi, A. (2017).Using digital stories to promote students' learning and understanding of poems in secondary school. Jurnal Sains Humanika, 9(4-2), 59-64. 